\title{
NORMATIVE EVOLUTION OF CHILD RIGHTS IN NIGERIA
}

Dr. Uchenna Emelonye*

*ICountry Representative, United Nations Office of the High Commissioner for Human Rights - LIBERIA

\section{(c) $(2)$ (1)}




\section{INTRODUCTION:}

The normative bedrock and corner-stone of modern human rights is the 'International Bill of Rights' (IBR) suspended by three-prong legs, one of which is the Universal Declaration of Human Rights (UDHR). While the UDHR did not articulate any child-specific human rights provision, a deductive reading of the broad spectrum of rights guaranteed in the Declaration disposes it as one of the strongest normative frameworks for the protection of child rights. As 'a first step in a great revolutionary process', the UDHR was intended not to be a binding legal instrument but instead a declaration of basic principles of human rights and freedoms.

In a bid to overcome the weaknesses of the UDHR and create a binding legal instrument, the United Nations Commission on Human Rights drafted a pair of binding covenants to complement the UDHR and constitute two of the three-prong stand of the IBR. They are the International Covenant on Civil and Political Rights (ICCPR) and the International Covenant on Economic Social and Cultural Rights (ICESCR). The ICCPR and ICESCR together with the UDHR form the IBR and jointly precipitated the expansion of international human rights standards in the form of treaties, declarations and conventions.

For the specific purpose of children, the ICCPR articulates special measures of protection and assistance for all children and young persons without any discrimination for reasons of parentage or other conditions. Ensuring that children and young persons should be protected from economic and social exploitation and while urging states to set age limits below which paid employment of a child should be prohibited, the ICESCR prohibits the employment of children in work harmful to their morals or health or dangerous to life or likely to hamper their normal development. The character of the obligations undertaken by State Parties differs from the ICCPR and ICESCR. Under the ICCPR, State Parties undertake to respect and to ensure to all individuals within their territory, the rights recognized in the covenant. On the other hand, the undertaking of State Parties under the ICESCR is to take measures to the extent of available resources with a view to achieving progressively the realization of the rights recognized in the Covenant. ${ }^{7}$

Whereas the IBR contains guarantees also applicable to children, there was the need for an international legal framework dealing specifically with children's particular needs. It was in response to the apparent need for a legally binding instrument focusing exclusively on the specific needs of children that the Convention on the Rights of the Child (CRC) was adopted. ${ }^{8}$ The CRC thus became the first legally binding international instrument to exclusively focus on children and accommodate all classes of rights including civil, cultural, economic, political and social rights.

At the regional level, the contemporary normative architecture of Africa's human rights system is linked to the coming into force of the Constitutive Act of the Organization of African Unity and culminated in the adoption of the African Charter on Human and Peoples Rights (ACHPR) in 1981. The Charter draws on international declarations and conventions to urge member States to ensure the protection of the rights of woman and the children. Motivated also by the enthusiasm to define and establish child rights within the parameters of the African value system, the African Charter on the Rights and Welfare of the Child (ACRWC) was adopted. It regionalizes the contents of the CRC, congregates all other laws conducive to the realization of the rights and welfare of the child and interprets universal child rights in the light of the socio-economic realities and traditions of Africa. While ensuring nondiscrimination like any other human rights instrument in the enjoyment of rights and freedoms, the ACRWC elevates the best interest of the child as the primary consideration in all actions undertaken by any person or authority and concerning any child.

As a signatory to all the major human rights instruments, Nigeria has ratified all the core human rights treaties and most of their Optional Protocols, including the ICCPR, ICESCR and CRC canvassed above. ${ }^{16}$ At the regional level, it has also ratified and domesticated all the applicable human rights treaties within the continent. Drawing its strength from international and regional treaties, the 1999 Constitution also guarantees expansive fundamental human rights which are equally applicable to children. However, the bill of rights provisions of the 1999 Constitution did not expressly mention children as distinct rights holders outside the generic fundamental human rights applicable to all.

Despite it commendable international and regional human rights and child rights treaty ratification record, and having regards to the dualist nature of its legal system, international and regional treaties are not automatically applicable

in Nigeria unless domesticated. It is for this reasons that the normative foundation of human rights in general and child rights in particular is not automatically derivable from the litany of international treaties accented to and ratified by Nigeria, but rather traceable to the Constitution of Nigeria and international and regional treaties domesticated in Nigeria through the acts of the National Assembly and enforceable nationally by the courts of law.

\section{Pre 2003 Child Rights Framework in Nigeria:}

Whereas the normative evolution of child rights at the global level is subsumed in the normative evolution of human rights, the case is different in Nigeria because the normative evolution of child rights is earlier in time and predates the articulation of any national human rights instrument. Arguably, the normative evolution of child rights in Nigeria is embodied in the Children and Young Persons Act (CYPA) passed in 1943 by the British Colonial Government as an Ordinance applicable throughout the Protectorate of Nigeria.

Prior to 2003, the child rights system in Nigeria was governed by an array of federal and state legislation. The first child specific legislation in Nigeria long before the adoption of any

Discrimination against Women; International Convention on the Elimination of All Forms of Racial Discrimination; International Covenant on Economic, Social and Cultural Rights; International Convention on the Protection of the Rights of All Migrant Workers and Members of Their Families; Convention on the Rights of Persons with Disabilities.

human rights specific instrument in the country is the CYPA and its amendments. It was originally intended to apply to Lagos but was later adopted as a regional law and subsequently as state laws. It was extended to the Eastern and Western 
Regions of Nigeria in 1946 and the Northern Region of Nigeria in 1958 through Order-in-Council of 1945 and 1958 respectively. ${ }^{20}$

As the major piece of legislation that was dealing with matters affecting children and young persons in Nigeria, the CYPA although promulgated to provide for the welfare and treatment of child offenders did not mention 'rights' in general or 'child rights' in particular in any of its provisions. ${ }^{21}$ Despite the 'rights' or 'child rights' omission of the text of the CYPA, Abubakar aptly alludes to the human rights ingredients of the CYPA when he states that it has a very strong focus on right based penal sanctions and at the same time articulated appropriate and mitigated responses to child offenses. ${ }^{22}$

On the introduction of a federal system of government with a state structure in Nigeria, most states of the federation enacted their own Children and Young Persons Law which were almost an identical reprinting of the 1943 CYPA. ${ }^{23}$ With the passage of time and more specifically, with the advancement in the better and clearer articulation of child rights in international and regional human rights instruments and laws, the inherent weaknesses of the CYPA began to emerge more visibly.

The CYPA did not define the word 'juvenile' nor was the word defined in any other piece of legislation simultaneously applicable with the CYPA. Like the penal and criminal codes applicable in Northern and Southern Nigeria respectively, the CYPA established two categories of children. The first is a 'child' defined as a person under the age of 14, and the second is a 'young person' defined as a person who has attained 14 years of age but is under the age of $17 .{ }^{24}$

Another defect of the CYPA in particular, and the rest of the pre-2003 legislation dealing with child rights in general, relates to the discrepancies in the age of criminal responsibility of children in conflict with the law. Rather than adopt a single age of criminal responsibility, the multiplicity of laws applicable at the same time as the CYPA adopted various age demarcations under which responsibility may or may not be assigned depending on the circumstances of the offense. While the gaps of the CYPA enumerated above are not exhaustive, suffice it to say that the CYPA remained the applicable law in matters relating to child rights for over 60 years in Nigeria.

In response to the foregoing child rights gaps in the CYPA and coupled with the need to develop national legislation on child rights that is aligned to international and regional human rights standards, the federal government of Nigeria initiated efforts to domesticate the CRC through the promulgation of the Child Rights Act (CRA).

\section{Legislative History of the Child Rights Act:}

There is a dearth of academic and other literature documenting the legislative history of the CRA. This academic gap may have caused the distorted, under-represented or misrepresented facts available on the subject. To attempt an overview of the legislative history of the CRA, efforts will be made to connect loose narratives on the subject matter. After its ratification of the CRC in 1991, Nigeria was the subject of intense national and international criticism due to the weakness of its child's rights framework on the one hand and its poor child rights record on the other hand. The reality of Nigeria's ineptitude in the protection of child rights intensified with the submission of its first country report to the Committee on the Right of the Child in 1996 and subsequent ratification of the African Charter on the Rights and Welfare of the Child (ACRWC) in 2001.

Predicated on the inherent gaps of the CYPA vis-a-vis international child rights standards in general, there was a very strong need to strengthen and align the Nigerian child rights legal framework with international human rights standards. In Ladan's view, efforts to promulgate the CRA were informed by the need for legislation that incorporates all the rights of children as well as articulates the duties and obligations of government, parents and other authorities. While this expedience accords with Nigeria's obligation under the CRC, the background to the adoption of the CRA was much politicized along ethnic, religious and cultural lines.

The first legislative effort to entrench a strong child rights regime that is compliant with international and regional normative standards initiated by the then military government of General Ibrahim Babangida did not result in a decree due to opposition from religious groups and traditionalists across the country. The ensuing limbo and disagreements over the content of the child rights legal framework persisted until General Babangida surrendered the country to the short-lived interim government of Ernest Shonekan. According to Alemika and Chukwuma, there was still a very divisive posture and inability to forge a common front during the interim government on the content of a child rights legislation.

At the end of the interim government of Shonekan and during the tenure of General Sani Abacha as Head of State, a special committee was also set up within the Ministry of Justice in 1995 to harmonize the draft child rights bill with diverse religious and cultural values in the country. The committee was also seized with the responsibility of analyzing the obstacles to the adoption of a country-wide and uniformly accepted child rights framework in compliance with international and regional standards. Incidentally, no progress was made in this direction throughout the five-year tenure of General Sani Abacha that terminated in 1999. Even the committee designated to articulate the draft child rights bill ended in disagreement and was polarized along religious and tribal lines to the point that no unanimously accepted report was adopted and presented for the consideration of the Head of State.

In early 2002 and under the democratically elected government of President Olusegun Obasanjo, the endeavor to promulgate child rights legislation was resuscitated once again with the preparation and presentation to the National Assembly of a bill providing for the rights and responsibilities of children in Nigeria, as well as for a renewed system of child justice. The difference between earlier endeavors to promulgate the child rights bill and the 2002 initiative was the fact that all the previous efforts happened during a military administration with no democratic posture and no reputation for respecting and observing human rights.

Incidentally, the first attempt at promulgating nationwide legislation on child rights in a democratic dispensation was once again rejected by the National Assembly in October 2002. It was disallowed on the same grounds of religious and cultural concerns akin to those that gave rise to the demise of initial efforts in 1993 and 1995 respectively. Citing the inconsistencies 
of the bill with religious values, traditions and cultures, it was stated that the majority of the members of the National Assembly, objected to the bill on grounds that it sets 18 years as the minimum age for marriage, amongst other things, contrary to religious and cultural traditions that allows 'marrying out' girls at a much younger age.

Distribution of Juvenile Delinquency in Metropolitan Lagos' (1984) 8 International Journal of Comparative and Applied Criminal Justice 187

According to Ogunniran, the Supreme Council for Shari'a in Nigeria pressured states in Northern Nigeria that are implementing Islamic law to impress their representatives in both the Senate and House of Representatives from supporting the draft bill. ${ }^{37}$ It was also recounted that the Supreme Council for Shari'a in Nigeria opposed the draft bill because of concerns that the bill would destroy the very basis and essence of Sharia and Islamic culture. ${ }^{38}$ The Council cited for instance the fact that the draft child rights bill accorded equal rights to male and female children on matters of inheritance, coupled with the fact that the creation of family courts under the bill impinges on the jurisdiction of Sharia court in all matters relating to children. ${ }^{39}$

Depicting the foregoing stern opposition to the draft child rights bill on religious grounds, Ojielo narrated that other subsidiary Islamic groups opposing the bill argued that as a federal state, Nigerian law, institutions and peoples must respect cultural diversities intrinsic in the nation, including religious beliefs and cultural practices.

The failure of the legislative efforts in 2002 to adopt a child rights bill, as against widely held expectations of easy passage due to its introduction in a democratically elected government, was not well received by national and international stakeholders. Civil society organizations and development partners were dissatisfied with the outcome of the child rights legislative process and thus mounted media pressure and persuaded the National Assembly towards reconsidering its decision not to pass the child's rights bill into law. ${ }^{42}$

In response to the progressively growing criticism and out-cry against the non-passage of the child rights bill and cognizant of the difficulties of articulating a culturally and religiously agreeable child rights legislation that is applicable to the entire federation, the $5^{\text {th }}$ National Assembly quickly moved into action and promulgated the CRA in 2003 pursuant to Section 299(a) of the 1999 Constitution. Despite the passage of the CRA and the litany of rights guaranteed for children, the scope of the CRA was undermined at birth due to the debilitating effects of the constitutional provision under which the National Assembly drew its powers to the pass it into law.

\section{Overview of the Child Rights Act:}

As an attempt to consolidate all laws relating to children into one single piece of legislation, the enactment of the CRA in 2003 also amounts to the implementation of Nigeria's commitment under international law to domesticate, recognize and enforce within its territory, the provisions of the CRC and the ACRWC. According to its preamble, the essence of the CRA is to provide and protect the rights of Nigerian children, and to secure their rights and interests irrespective of their parents' or guardian's state of origin, ethnic nationality, sex, race and circumstances of birth, political opinion or religion. Abubakar supports the spirit of the CRA when he posits that the CRA is aimed at boosting and extending the frontiers of existing legislation contained in different federal and state laws protecting the rights and interest of Nigerian children.

Structurally, the CRA is divided into twenty four parts and eleven schedules. Apart from providing for specific rights for children in conflict with the law, the CRA, while adopting all the fundamental rights in Chapter IV of the 1999 Constitution, creates a host of other child rights. In line with Africa-centric balancing of rights and responsibilities and in a bid to channel the energy of children towards building a healthy and prospective Nigerian nation, Section 19 of the CRA imposes on the child corresponding duties towards his or her family, community and the Federal Republic of Nigeria.

The Act also contains 16 distinct human rights for children including the right to survival and development, the right to a name, freedom of association and peaceful assembly, freedom of thought, conscience and religion, the right to private and family life, the right to freedom of movement, and freedom from discrimination. Others are the right to dignity of the child, the right to leisure, recreation and cultural activities, the right to health and health services, the right to parental care, protection and maintenance, and the right to free, compulsory and universal primary education.

\section{Federalism and Child Rights in Nigeria}

Nigerian federalism has rotated between the excessive regionalization that characterized the first republic to the excessive centrality of the military and to some extent, post-military political era. This transition has been accompanied by structural changes, which religious diversities of the country, securing the participation of the State Houses of Assembly as envisaged under the Constitution for the enactment of a Child Rights Act that is uniformly applicable country wide was apparently impossible. saw the federation move from its initial three regions at independence to its present 36 state structure and 774 local government councils. With federalism being one of the constitutional principles of the 1999 constitution, the distribution of powers across the three-tier federal structure consisting of the federal government, the state government and local government is guaranteed in the constitution.

Each level of government has under the 1999 constitution specified legislative autonomy within its area of operation. Part I of the 1999 Constitution provides for the exclusive legislative list which itemizes issues in respect of which the federal government has exclusive competence to legislate upon. The subject matter for which the federal government could exclusively legislate upon excludes human rights in general and child rights in particular. While the federal government has the sole competence to legislate on matters on the exclusive legislative list, the subject matter on the concurrent legislative list provided for in Part II of the constitution could be legislated upon by both the federal and state government. Like the exclusive legislative list, the concurrent legislative list omits itemizing human rights in general and child rights in particular as express matters that could be legislated upon by state governments. 
For the purposes of domesticating a treaty, Section 12(2) of the 1999 Constitution authorizes the National Assembly to make laws for the federation or any part thereof with respect to matters not included in the Exclusive Legislative List. Limiting the scope of Section 12(2), section 12(3) of the 1999 Constitution provides a further caveat that a law passed by the National Assembly outside matters enumerated on the Exclusive Legislative List shall not be enacted into law unless it is ratified by a majority of all the House of Assembly of States of the federation.

The condition precedent to Section 12(3) of the 1999 Constitution is that the National Assembly requires two-thirds of the state houses of assembly to promulgate legislation on a matter outside the Exclusive Legislative List. Realizing that issues relating to child rights are outside the legislative competence of the National Assembly because it is not enumerated on the Exclusive Legislative List, and cognizant of the unlikelihood of securing the constitutionally required two-thirds votes of State House of Assembly if the CRA were to be applicable throughout the federation, the National Assembly enacted the CRA pursuant to Section 299(a) of the 1999 Constitution wherein it is only applicable within the FCT.

\section{Conclusion:}

The promotion and protection of child rights have assumed global appeal and also gained remarkable attention among the comity of nations. As a member state of the United Nations and African Union, Nigeria has subscribed to virtually all international and regional child rights instruments and domesticated them through its constitution in general and the CRA in particular. While the CRA meets international and regional thresholds for the protection of child rights and is the normative framework for addressing the practical constraints and deficiencies of the extant laws on children in Nigeria, the CRA is fraught with endemic challenges having been enacted under Section 299(a) of the 1999 Nigerian Constitution. The unintended effect of 1999 Constitution on child rights is that it has negated the application of the CRC and ACRWC in Nigeria and further slowed down the realization of the gains of the CRA.

Although the 1999 Constitution guarantees expansive fundamental human rights which are equally applicable to children and bearing in mind that no express mention of children as distinct rights holders outside the generic fundamental human rights applicable to all human being was made in the constitution, the constitutional framework in Nigeria is not in consonance with the contemporary trend of mainstreaming child rights through express mention in the bill of rights provisions of the constitution. For instance, the 2010 Constitution of Kenya, makes it a fundamental duty of the state and every state organ to observe, respect, protect, promote and fulfil the rights and fundamental freedoms in the bill of rights. It also entrusts on all state organs and all public officers, the duty to address the needs of vulnerable groups within society, including women, older members of society, persons with disabilities, children, youth, members of minority or marginalized communities, and members of particular ethnic, religious or cultural communities. The Kenyan constitution also enjoins the state to enact and implement legislation to fulfil its international obligations in respect of human rights and fundamental freedoms. Bearing in mind the hierarchy of the constitution vis-à-vis other national laws in Nigeria, express mention of child rights in the bill of rights provisions of the 1999 Constitution portends inherent advantages.

While the adoption of the CRA under Section 299(a) of the 1999 Constitution appears to be a quick fix to existing challenges of child rights in Nigeria, it is however not a durable solution to the defects it intended to cure. As a minimalistic approach at domesticating international and regional child rights frameworks, one of the CRA's major drawback relates to its limited scope to only the Federal Capital Territory and the fact that it possibly allows state houses of assembly the exclusive jurisdiction to legislate on child rights, because they belong to the residual legislative list which is not expressly reserved for the National Assembly under the Exclusive Legislative List or under the Concurrent Legislative List.

There is apparently no literature that has canvassed the justification behind the omission of human rights in general and child rights in particular from the extensive list or arguably over bloated matters reserved for the national Assembly under the Exclusive Legislative List. There is also non that has adduced why human rights and child rights were equally omitted from the Concurrent Legislative List. The nearest inference is that because matters relating to children are often considered welfare issues in Nigeria, the drafters of the 1999 Constitution and other constitutions before it may have been so influenced to perceive child rights as synonymous with welfare issues which are best situated within the subsidiary basket of the residual legislative list devolved to state legislative competence. There is no gainsaying the fact that the blanket classification of matters of child rights as welfare issues best suited and relegated to the third-class residual legislative list is certainly untenable.

Assuming, but not conceding that the rationale for situating child rights as welfare issues suitable for the residual legislative list of the 1999 Constitution is justifiable, it is doubtful what reasoning was applied by the drafters of the constitution in also omitting legislating for human rights from the priority Exclusive Legislative List and at the very least the Concurrent Legislative List. The consequential de-emphasis of human rights and child rights by this constitutional omission or commission is inconsonant with the priority status that ought to be placed on human rights and by extension child rights. The best practice is that legislating for a matter as important as human rights or child rights should have been made the prerogative of the Federal Government of Nigeria, in which case such legislative powers ought to have been allocated to the Exclusive Legislative List for the remit of the National Assembly. Bearing in mind that the CRA was enacted pursuant to Section 299(a) of the 1999 Nigerian Constitution and applicable only the FCT, it therefore follows that states of the federation are allowed to adopt or not to adopt their state specific child rights legal frameworks, which are most often not always in consonance with the CRA, regional and international standards. This situation presents a potential for discrepant laws capable of enabling discrepant treatment of children amongst states of the federation and thus defeats the philosophy behind the CRC, the ACRWC and ultimately the CRA.

In the present unstandardized child rights normative framework in Nigeria, children are not uniformly availed the enjoyment of the protective shield of the CRA because some states of the federation are still applying the outdated and unfriendly framework of the CYPA. To ensure that children all over Nigeria and irrespective of their state of domicile 
receive same protection under the law, the CRA ought to be applicable to the entire federation, or at least adopted by all the 36 states of the federation into a state law.

In view of the foregoing, there is a necessity to reconsider Section 12(1) of the 1999 Constitution by excluding treaties relating to human rights in general and child rights in particular from its purview. Noting the importance of child rights as vehicles for good governance and bearing in mind that the treaty domestication process of the National Assembly is further impinged by the division of legislative functions between the federal and state governments, treaties relating to human rights in general and child rights in particular adopted by the Federal Government of Nigeria should not be subjected to a domestication process by the National Assembly and endorsement by state houses of assembly as the case may be. By this argument and on the basis of pacta sunt servanda, Nigeria will be bound by all human rights instruments and laws it ratifies including the $\mathrm{CRC}$ and the ACRWC.

This proposition is based on the fact that the dichotomy between international human rights law and national human rights law is becoming more fluid by the day to the extent that international human rights treaties adopted by countries are automatically beginning to have the force of law nationally. For instance, in the context of Kenya which is also a common law country, the 2010 Kenya Constitution supports this postulation. Article 2(5) of the 2010 Kenyan Constitution provides that the general rules of international law shall form part of the law of Kenya. Also Sub-section 2(6) provides further that any treaty or convention ratified by Kenya shall form part of the law of Kenya under its constitution. If a provision similar to this is introduced into the constitutional framework of Nigeria, the existing discrepancy between international human rights standards subscribed to by Nigeria and its national human rights framework would be reconciled in favor of the former.

Express incorporation of Nigeria's international and regional human rights obligations into applicable national laws devoid of the need for domestication is a very feasible option for Nigeria. If a window of constitutional reform opens in Nigeria, legislating for human rights and child rights in particular should be introduced to the Exclusive Legislative List so as to ensure that the National Assembly can exclusively legislate on human rights and child rights to the extent that any law made towards domesticating an international human rights obligation would automatically be applicable to the entire country. In that case, the domestication of international human rights treaties, enacting laws for the fulfillment and implementation of international human rights obligations subscribed to by Nigeria and ultimately the setting of national human rights standards should not be subject to Section 12 (1) of the 1999 Constitution requiring the concurrence of the majority of the state houses of assembly before the National Assembly would enact such a treaty into law. If legislating for human rights and child rights were within the remit of the Exclusive Legislative List, the CRA as promulgated by the National Assembly would automatically have the force of law in all the states of the federation.

\section{References}

[1] Country Representative, United Nations Office of the High Commissioner for Human Rights -LIBERIA; LL.D University of Helsinki Finland; LL.M - Central European University Budapest Hungary; LL.M - Abia State University Nigeria; BL - Barrister and Solicitor of the Supreme Court of Nigeria; LL.B - Abia State University Nigeria; (emelonye@gmail.com) This paper is written in a personal capacity and does not represent the views of the United Nations.

[2] UN General Assembly, Universal Declaration of Human Rights, 10 December 1948; See also Mary Ann Glendon, A World Made New: Eleanor Roosevelt and the Universal Declaration of Human Rights. (Random House Publishing Group 2002); Deaton Matt, Universal Declaration of Human Rights(Springer 2011)

[3] Kathleen Renee Cronin-Furman, '60 Years of the Universal Declaration of Human Rights: Towards An Individual Responsibility to Protect' (2010) 25 American University International Law Review 175

[4] UN General Assembly, International Covenant on Civil and Political Rights, 16 December 1966; See also Linda Camp Keith, 'The United Nations International Covenant on Civil and Political Rights: Does It Make a Difference in Human Rights Behavior'? (1999) 13 Journal of Peace Research 195

[5] UN General Assembly, International Covenant on Economic, Social and Cultural Rights, 16 December 1966; See also Craven, Matthew, The International Covenant on Economic, Social and Cultural Rights: A Perspective on its Development (Clarendon Press 1995)

[6] Article 10 (1)(3) UN General Assembly, International Covenant on Economic, Social and Cultural Rights, 16 December 1966

[7] Rajsoomer Lallah, 'Notes on the International Covenant on Civil and Political Rights and Some of Its Case Law' (1992) 18 Common Wealth Law Bulletin 1258

[8] UN General Assembly, Convention on the Rights of the Child, 20 November 1989; See also Sonia Harris-Short, 'International Human Rights Law: Imperialist, Inept and Ineffective? Cultural Relativism and the UN Convention on the Rights of the Child' (2003) 25 Human Rights Quarterly 130; McGoldrick Dominic, 'The United Nations Convention on the Rights of the Child' [1991] International Journal of Law, Policy and the Family 132

[9] Thomas Hammarberg, 'The U.N Convention on the Rights of the Child - and How to Make it Work'(1990) 12 Human Rights Quarterly 97

[10] Chidi Anselm Odinkalu, 'Africa’s Regional Human Rights System: Recent Developments and Jurisprudence' (2002) 2 Human Rights Law Review 99; See also Ademola Abass and Mashood A. Baderin, 'Towards Effective Collective Security and Human Rights Protection in Africa: An Assessment of the Constitutive Act of the New African Union' (2002) 49 Netherlands International Law Review 1

[11] Organization of African Unity (OAU), African Charter on Human and Peoples' Rights ('Banjul Charter') 27 June 1981; See also B. Obinna Okere,'The Protection of Human Rights in Africa and the African Charter on Human and 
Peoples' Rights: A Comparative Analysis with the European and American Systems' (1984) 6 Human Rights Quarterly 141

[12] Article 18, African [Banjul] Charter on Human and Peoples' Rights, adopted June 27, 1981, OAU Doc. CAB/LEG/67/3 rev. 5, 21 I.L.M. 58 (1982), entered into force Oct. 21, 1986

[13] Organization of African Unity (OAU), African Charter on the Rights and Welfare of the Child, 11 July 1990 ; See also Dejo Olowu, Protecting Children's Rights in Africa: A Critique of the African Charter on the Rights and the Welfare of the Child' (2002) International Journal of Child Rights 127

[14] Organization of African Unity (OAU), African Charter on Human and Peoples' Rights ('Banjul Charter') 27 June 1981Art 3 and 4, African Charter on the Rights and Welfare of the Child, 11 July 1990

[15] They are Convention against Torture and Other Cruel Inhuman or Degrading Treatment or Punishment; International Covenant on Civil and Political Rights; Convention for the Protection of All Persons from Enforced Disappearance; Convention on the Elimination of All Forms of Discrimination against Women; International Convention on the Elimination of All Forms of Racial Discrimination; International Covenant on Economic, Social and Cultural Rights; International Convention on the Protection of the Rights of All Migrant Workers and Members of Their Families; Convention on the Rights of Persons with Disabilities.

[16] Chilenye Nwapi, 'International Treaties in Nigerian and Canadian Courts' (2011) 19 African Journal of International and Comparative Law 38; See also Edwin Egede, 'Bringing Human Rights Home: An Examination of the Domestication of Human Rights Treaties in Nigeria' (2007) 51 Journal of African Law 249; A O Enabulele, 'Implementation of Treaties in Nigeria and the Status Question:

[17] Whither Nigerian Courts' (2009) 17 African Journal of International and Comparative Law 326. See also Section 12 Constitution of the Federal Republic of Nigeria, 1999

[18] The 1943 Ordinance was subsequently amended through several pieces of legislation (i.e.Ordinances 44 of 1945); Ordinance 27 of 1947; Ordinance 16 of 1950 as well as its mutation to the Laws of Nigeria 131 of 1954; Laws of Nigeria 47 of 1955) and Order in Council 22 of 1946. The Act was intended as a national law, Cap 32 Laws of the Federation of Nigeria and Lagos 1958, but was eventually adopted as regional laws and subsequently as state laws.

[19] This included the Children and Young Persons Act (CYPA); the Criminal Code Act; the Criminal Procedure Act; the Criminal Code Laws and the Criminal Procedure Laws applicable in Southern Nigeria (except Lagos state); the Penal Code Act and Criminal Procedure Code applicable as federal legislation in the Federal Capital Territory of Abuja and the Penal Code Laws of the state and the Criminal Procedure Codes applicable as state legislations in the Northern Nigeria. These pieces oflegislation that delineate the mutually reinforcing powers of the three justice institutions are potentially triggered from any of the 36 states of the federation and the Federal Capital Territory through an infraction of the law.19

[20] Etannibi Alemika and I.C. Chukwuma, Juvenile Justice Administration n in Nigeria: Philosophy and Practice, (CLEEN Foundation 2001) 16

[21] Isabella Okagbue, 'Children in Conflict with the Law: The Nigerian Experience' < http://www.unicefirc.org/portfolios/documents/487 nigeria.htm > accessed October 26 2013; See also E.E. Alemika and I.C Chukwuma, Juvenile Justice Administration in Nigeria: Philosophy and Practice, (Center for Law Enforcement Education 2001)

[22] Musa Usman Abubakar, 'Criminal Law and the Rights of the Child in Northern Nigeria' (2010) Legal Studies Research Paper No 2012 <http://ssrn.com/abstract=2055162> accessed 11 April 2014

[23] Laurent Fourchard, 'Lagos and the Invention of Juvenile Delinquency in Nigeria 1920 - 60' (2006) 47 Journal of African History115; See also Simon Heap, 'Their Days are Spent in Gambling and Loafing, Pimping for Prostitutes, and Picking Pockets: Male Juvenile Delinquents on Lagos Island 1920s-1960s' (2010) 35 Journal of Family History 48

[24] Hakeem Ijaiya, 'Juvenile Justice Administration in Nigeria' (2009) 2 NUJS Law Review 573; See also L Fourchard, 'The Making of the Juvenile Delinquent in Nigeria and South Africa, 1930-1970' (2010) 8 History Compass 129; Olayinka Atiola, 'Juvenile/Youth Justice Management in Nigeria: Making a Case for Diversion Programmes' (2013) 3 Youth Justice 3

[25] E.E.Alemika and I.C Chukwuma, Juvenile Justice Administration in Nigeria: Philosophy and Practice (Center for Law Enforcement Education 2001)

[26] Etannibi Alemika, Innocent Chukwuma and others, Rights of the Child in Nigeria: Report on the Implementation of the Convention on the Rights of the Child by Nigeria. (WOAT and CLEENFoundation 2005) 5

[27] UN Committee on the Rights of the Child: Concluding Observations of the Committee on the Rights of the Child, Nigeria, (U.N. Doc. CRC/C/15/Add. 61 1996) < http://www1.umn.edu/humanrts/crc/nigeria1996.html> accessed 15 December 2013

[28] Laurent Fourchard, 'Lagos and the Invention of Juvenile Delinquency in Nigeria 1920 - 60' (2006) The Journal of African History; See also Laurent Fourchard, 'The Limits of Penal Reform: Punishing Children and Young Offenders in South Africa and Nigeria 1930s to 1960' (2011) 37 Journal of Southern African Studies 517

[29] Mohammed Tawfiq Ladan, 'The Child Rights Act 2003 and the Challenges of its Adoption By State Governments in the 19 Northern States' (2007) Seminar Paper at the Interactive Forum for Sokoto State House of Assembly Legislators (On file)

[30] E.E. Alemika and I.C Chukwuma, Juvenile Justice Administration in Nigeria: Philosophy and Practice (Center for Law Enforcement Education 2001); See also Obi Ignatius Ebbe, 'EcologicalDistribution of Juvenile Delinquency in Metropolitan Lagos' (1984) 8 International Journal of Comparative and Applied Criminal Justice 187

[31] Ibid 
[32] Etannibi Alemika, Innocent Chukwuma and others, Rights of the Child in Nigeria: Report on the Implementation of the Convention on the Rights of the Child by Nigeria (WOAT and CLEENFoundation 2005) 5

[33] Penal Reform International, 'Report on the National Conference on Juvenile Justice Administration in Nigeria. Abuja (July 2002) <http://www.penalreform.org/wp-content/uploads/2013/06/rep2002-nigeria-juvenile-justice-en.pdf> accessed 12 May 2012; See also Nkoyo Toyo, 'Revisiting Equality as a Right: the Minimum Age of Marriage Clause in the Nigerian Child Rights Act 2003'

[34] (2006) 27 Third World Quarterly 1299

[35] Iyabode Ogunniran, 'The Child Rights Act Versus Shari'a Law in Nigeria: Issues, Challenges and A Way Forward' (2010) 30 Child Rights Journal 62

[36] Nkoyo Toyo, 'Revisiting equality as a right: the minimum age of marriage clause in the Nigerian Child Rights Act, 2003' (2006) 27 Third World Quarterly 1299

[37] Penal Reform International, 'Northern Zonal Consultative Conference on Juvenile Justice Administration in Nigeria, Kano’ (September 2002) <http://www.penalreform.org/wp-content/uploads/2013/06/rep-2002-nigeria-juvenilejustice-en.pdf> accessed 12 May 2012

[38] Iyabode Ogunniran, 'The Child Rights Act Versus Shari'a Law in Nigeria: Issues, Challenges and A Way Forward' (2010) 30 Child Rights Journal 62

[39] E.E. Alemika and I.C Chukwuma, Juvenile Justice Administration in Nigeria: Philosophy and Practice, (Center for Law Enforcement Education 2001); See also Obi Ignatius Ebbe, ' Juvenile Delinquency in Nigeria: The Problem of Application of Western Theories’ (1992) 16 International Journal of Comparative and Applied Criminal Justice 35339 Ibid

[40] Ozonnia M Ojielo, 'Human Rights and Sharia'h Justice in Nigeria' (2003) 9 Annual Survey of International and Comparative Law 135; Pavani Thagirisa, 'Historical Perspective of the Sharia Project and a Cross-Cultural and SelfDetermination Approach to Resolving the Sharia Project in Nigeria' (2004) 29 Brooklyn Journal of International Law 459; See also Brabdon Kendhammer, 'Islam and the Language of Human Rights in Nigeria: 'Rights Talk' and Religion in Domestic Politics' (2013) 12 Journal of Human Rights 469

[41] Penal Reform International, 'Southern Zonal Consultative Conference on Juvenile Justice Administration in Nigeria, Ibadan' (October 2002) <http://www.penalreform.org/wpcontent/uploads/2013/06/rep-2002-nigeria-juvenilejustice-en.pdf> accessed 12 May 2012

[42] E.E. Alemika and I.C Chukwuma, Juvenile Justice Administration in Nigeria: Philosophy and Practice, (Center for Law Enforcement Education 2001); See also Obi Ignatius Ebbe, 'Juvenile Justice System In Southern Nigeria' (1998) 12 International Journal of Comparative and Applied Criminal Justice 194

[43] Section 299(a) Constitution of the Federal Republic of Nigeria 1999 provides that all the legislative powers, the executive powers and the judicial powers vested in the House of Assembly, the Governor of a State and in the courts of a State shall, respectively, vest in the National Assembly, the President of the Federation and in the courts which by virtue of the foregoing provisions are courts established

[44] for the Federal Capital Territory, Abuja. It should also be noted that owing to the promulgation history of the Child Rights Act which was fraught with polarization based on manifest cultural andreligious diversities of the country, securing the participation of the State Houses of Assembly as envisaged under the Constitution for the enactment of a Child Rights Act that is uniformly applicable

[45] country wide was apparently impossible.

[46] Musa Usman Abubakar, 'Criminal Law and the Rights of the Child in Northern Nigeria' (2010) Legal Studies Research Paper No 2012 - 11 <http://ssrn.com/abstract=2055162> accessed 11 April 2014

[47] Section 3 - 17 Child Rights Act 2003; See also Nkoyo Toyo, 'Revisiting Equality as a Right: the Minimum Age of Marriage Clause in the Nigerian Child Rights Act 2003' (2006) 27 Third World Quarterly 1299

[48] Ladipo Adamolekun, 'The Nigerian Federation at the Crossroads: The Way Forward' (2005) 35 Publius 383

[49] Rotimi Suberu, 'The Nigerian Federal System: Performance, Problems and Prospects' [2010] Journal of Contemporary African Studies 459

[50] Section 2 Constitution of the Federal Republic of Nigeria, 1999

[51] Article 21 (1) Constitution of Republic of Kenya Ibid

[52] Marie-Antoinette Sossou and Joseph A Yogtiba, 'Abuse of Children in West Africa: Implications for Social Work Education and Practice' (2009) 39 British Journal of Social Work 1218; J Hagen-Zankerand R Holmes, 'Social Protection in Nigeria: Synthesis Report'. (2012) ODI/UNICEF Nigeria; See also R Holmes and Others 'Social Protection in Nigeria: Mapping Programmes and Their Effectiveness"

[53] (2012) ODI/UNICEF Nigeria; N Jones and Others, 'Promoting Synergies Between Child Protection and Social Protection in Nigeria' (2012) ODI/UNICEF Nigeria

[54] Jim Ife, Human Rights and Social Work: Towards Rights Based Practice (3rd edn Cambridge University Press 2012) 17; See also Jim Ife and Lucy Fiske, 'Human Rights and Community Work. Complementary Theories and Practices' (2006) 49 International Social Work 297; UN General Assembly, Convention on the Rights of the Child, 20 November 1989 